\title{
Long term Follow up Result of Posterior Urethral Valve Management
}

\author{
Richa Jaiman and Punit Srivastava* \\ Department of Pediatric Surgery, S N Medical College Agra, India
}

Submission: December 01, 2017; Published: February 06, 2018

*Corresponding author: Puneet Srivastava, Associate Professor Surgery, S N Medical College Agra, UP, India, Tel: 919319966783 ; Email: drpunit979@gmail.com

\section{Abstract}

Introduction: Posterior urethral valve (PUV) is a commonest cause of urinary outflow obstruction leading to childhood renal failure, bladder dysfunction and somatic growth retardation. The incidence of PUV is 1 in 5000 to 8000 male birth. The objective and scope of present study is to compare the long term result posterior urethral valves that are managed by different techniques at our institute.

Material and Methods: Study was carried out in S N Medical college Agra India. It is a retrospective study of the patients who were managed from 2007-17 and followed up in our department.

Results: $76 \%$ patients presented with urinary symptoms, $16.7 \%$ presented with septicemia and $6.3 \%$ presented with failure to thrive. Valve ablation was the primary mode of treatment in 23 patients, vesicostomy 5 patients and high diversion in 2 patients. Vesicoureteric reflux was present in 26 patients. According to IAP classification of growth and development 17 patients were normal 4 patients had PEM grade - I and 3 patients in each grade II, III and IV. 4 patients developed chronic renal failure and 3 patients had stage renal disease.

Conclusion: Posterior urethral valve is a dynamic disease that can have lifelong effects on bladder. These patients need long term follow up care to monitor and treat the effects of altered bladder compliance.

Keywords: Posterior urethral valve; Bladder dysfunction; Ureteric reflux; Hyperreflexia; Cystourethrography

Abbreviations: PUV: Posterior Urethral Valve; VCUG: Voiding Cystourethrography; VCU: Voiding Cystourethrogram

\section{Introduction}

Posterior urethral valve (PUV) is a commonest cause of urinary outflow obstruction leading to childhood renal failure, bladder dysfunction and somatic growth retardation. The incidence of PUV is 1 in 5000 to 8000 [1] male child. The exact etiological factor which leads to development of the PUV and associated bladder, ureteric and renal abnormality have not been elucidated but it may appear to be multi factorial and may include a combination of teratogenic and gene mediated embryopathy.

The commonest clinical presentation is urinary symptoms [2] (poor urinary stream followed by dibbling of urine) and severe septicemia, respiratory distress and failure to thrive. Generalized distention of abdomen is more common in younger age group especially in neonate along with urinary ascitis [3]. The incidence of palpable kidney, hypertrophied bladder on bimanual palpation was documented to be higher.

The standard procedure for its management include primary valve ablation by different modalities with or without primary urinary diversion depending upon the general condition of patient, renal functional status, presence of ureteric reflux, tortusity, dilatation, infection and associated dysplasia of kidney.

The bladder dynamics change with growth of the baby and hypertonicity decreases with time following valve ablation while hyperreflexia persist leading to bladder dysfunction and urinary incontinence. Patients were kept in strict follow up to prevent long term complication.

A complete imaging work-up including a voiding cystourethrography (VCUG) and renal scintigraphy is the diagnostic gold standard for the detection of nephrouropathies in children with fetal pyelectasis [4]. DMSA and DTPA renal scan was also the two important pillars in assessing the result of management during follow up period. Serum creatinine, blood urea and regular microscopic examination of urine for pus cells also help in assessing renal functional status. The objective of present study is to compare the long term result of PUV patients who are managed by different modalities at our centre. Evaluation of patients was done on anatomical status of both upper and lower urinary tract, renal function tests, urinary incontinence and somatic growth pattern. 


\section{Method}

Study is conducted in Institute of Medical Sciences BHU, Varanasi India, a detailed history, general examination, per abdomen examination, examination of external genitalia, urine examination, hematological examination, biochemical examination, ultrasonography, voiding cystourethrogram, intravenous urography and renal scan was done for every patients.

Treatment protocol at our centre is: initial treatment is intravenous fluid, urinary catheter, correction of acid base balance and electrolyte, detailed urinary analysis and intravenous antibiotics. After 48 - 72 hours of the initial management all patients were subjected to voiding cystourethrography (VCU) and than planned for definitive procedure (primary valve ablation) between 5 to 7 days. After the valve fulguration indwelling catheter is kept for 48 hours. After this result of primary valve ablation is being assessed by observing the urinary stream and per abdominal examination. If the results are not satisfactory a trial of repeat fulguration is given. If still the condition is not improved urinary diversion is done either $n$ form of vesicostomy (without VUR) or cutaneous ureterostomy (in case of gross VUR).

\section{Follow up protocol}

We follow the cases of PUV initially at 15 days interval for $1^{\text {st }} 3$ months, then monthly for next 6 months, then every 3 months for 5 years and every year till 20 years. The simplest way of assessing the progress is weekly urine for pus cells and maintaining the register of it by the parent. In cases if gross VUR (grade IV \& V) prophylactic antibiotics are continued till reflux subsides (detected by USG) or some antireflux procedure has been implemented.

\section{Following investigation are done for deciding future course of action}

Blood urea and serum creatinine and urine culture and sensitivity every monthly for $1^{\text {st }}$ year and then every 6 monthly for 5 years, abdominal USG for kidney size, ureters and bladder fir VUR and post void residual urine volume every 6 months for first 3 years and then yearly for 20 years. VCU to diagnose persistent vesiocureteric reflux following treatment, DTPA \& DMSA scan where there is persistently high creatinine level even after urinary diversion or USG revealed definitive evidence of cystic dysplasia or marked renal scaring. It is also repeated just before unidiversion/ nephrouretrectomy. Blood pressure is also monitored regularly. IVU is repeated within $1^{\text {st }}$ year of surgery for PUV to assess the improvement of renal function when the serum creatinine become normal. Urodynamic study is done when there is raised creatinine level above $2 \mathrm{mg} \%$ but less than $5 \mathrm{mg} \%$ or the patients are having some residual symptoms even after primary valve ablation in the form of inadequate, incomplete, frequent voiding or incontinence inspite of good stream. After elaborative study of PUV patients follow up and its management statistical analysis was done with Mann Whitney test for quantitative variables and Fisher exact test for qualitative variables. The patients were divided in four groups according to age of presentation.

\section{Results}

A total of 120 patients were included in our study that was regularly followed up in our ward. Nearly $13.3 \%$ patients present before 3 months (group - I). 47.6\% patients presented between 4 months to 1 year of age (group - II). $20 \%$ presented between 1 year and 5 year (group - IIII) and 20\% presented after age of 5 year (group - IV) (Table 1). 23 patients (76.7\%) presented with urinary symptoms (poor urinary stream, dribbling of urine \& retention of urine) 20 patients (16.7\%) presented with severe septicemia and respiratory distress and $10(6.6 \%)$ presented with failure to thrive (Table 2). On clinical examination abdominal distension was present in 16 patients $(13.3 \%)$ and 12 patients $(10 \%)$ presented with urinary ascitis. The incidence of palpable and enlarged kidney was found in 40 patients (33.3\%). Presence of hypertrophied and distended bladder on bimanual palpation present in 42 (43.3\%) patients. At presentation approximately $95 \%$ patients had raised blood urea and serum creatinine levels and at one month of followup serum level remained high in $57 \%$ of cases. At 1 mean year of age of follow-up $33 \%$ of patients had mean serum creatinine more than $2.9 \mathrm{mg} / \mathrm{dl}$. At 2.5 mean years age of follow-up $23 \%$ of patients had serum creatinine level above $3.1 \mathrm{mg} / \mathrm{dl}$, at mean 5 year of follow-up $10 \%$ of patients had serum creatinine more than $4.3 \mathrm{mg} / \mathrm{dl}$ at 7.5 years and at 10.7 mean year follow-up age $10 \%$ had serum creatinine more than $8.2 \mathrm{gm} / \mathrm{dl}$ (Table 3 ). We had followed the patients presented to us in different age group and summaries that children presented in group I consist patients with mean age of 1.5 month of age at presentation and mean age of valve ablation was 1.5 months and the mean age of their last follow up is 7 years. The group II comprises the mean age of presentation of patients was 6.3 months along with mean age of valve ablation was 7.1 months and mean age of last follow up was 6.6 years. Group III comprises patients with mean age of presentation is 30 months and mean age of valve ablation was 32 months along with mean age of last follow up was 9.5 year and lastly group IV consist of children with more than 5 years, whose mean age at presentation was 102 months and mean age of valve ablation was 105 months along with mean age of last follow up was 18 years (Table 4).

Table 1: Age of presentation: $1(\mathrm{n}=120)$.
\begin{tabular}{|c|c|c|c|}
\hline Group & $\begin{array}{c}\text { Age at } \\
\text { Presentation }\end{array}$ & No. of Cases & $\%$ \\
\hline I & $0-3$ months & 16 & $13.3 \%$ \\
\hline II & $4-12$ months & 56 & $46.7 \%$ \\
\hline III & $13-60$ months & 24 & $20 \%$ \\
\hline IV & $>60$ months & 24 & 2 \\
\hline
\end{tabular}


Table 2: Clinical presentation.

\begin{tabular}{|c|c|c|c|}
\hline \hline Symptoms & S & Sign & Hypertrophied and distended bladder \\
\hline Urinary symptoms & $76.7 \%$ & Palpable \& enlarged kidney & $43.3 \%$ \\
\hline Septicemia with respiratory distress & \multirow{2}{*}{$16.7 \%$} & Generalized distension of abdomen in neonate & $33.3 \%$ \\
\hline Failure to thrive & $6.6 \%$ & Urinary ascitis & $13.4 \%$ \\
\hline
\end{tabular}

Table 3: Means creatinine level at subsequent mean year of age.

\begin{tabular}{|c|c|c|c|c|c|c|c|c|c|c|c|}
\hline \multirow{2}{*}{\multicolumn{2}{|c|}{ Primary Treatment Group }} & \multicolumn{2}{|c|}{1 year } & \multicolumn{2}{|c|}{2.5 year } & \multicolumn{2}{|c|}{5 year } & \multicolumn{2}{|c|}{7.5 year } & \multicolumn{2}{|c|}{10 year } \\
\hline & & No. & $\mathrm{Cr}$ & No. & $\mathrm{Cr}$ & No. & $\mathrm{Cr}$ & No. & $\mathrm{Cr}$ & No. & $\mathrm{Cr}$ \\
\hline A & Pr. Valve ablation & 20 & 3.2 & 16 & 2.8 & 12 & 3.2 & 4 & 4.1 & 4 & $>8.2$ \\
\hline B & Vesicostomy & 12 & 2.4 & 8 & 2.6 & 8 & 3.8 & 4 & 4.3 & 4 & $>8.2$ \\
\hline $\mathrm{C}$ & High Diversion & 8 & 3.1 & 4 & 4.1 & 8 & 4.2 & 4 & 4.9 & 4 & $>8.2$ \\
\hline
\end{tabular}

Table 4: The statistical comparison between various treatment group.

\begin{tabular}{|c|c|c|c|c|c|c|}
\hline \hline Groups & & $\mathbf{1} \mathbf{~ y r}$ & $\mathbf{2 . 5} \mathbf{y r}$ & $\mathbf{5} \mathbf{~ y r}$ & $\mathbf{7 . 5} \mathbf{~ y r}$ & $\mathbf{1 0} \mathbf{~ r r}$ \\
\hline \multirow{2}{*}{ A vs C } & UL & 0.99 & 0.95 & 0.97 & 0.97 & 0.97 \\
\cline { 2 - 7 } & LL & 0.12 & 0.29 & 0.20 & 0.33 & 0.33 \\
\hline \multirow{2}{*}{ A vs C } & UL & 1.00 & 0.97 & 1.00 & 1.00 & 1.00 \\
\cline { 2 - 7 } & LL & 0.07 & 0.37 & 0.33 & 0.156 & 0.156 \\
\hline \multirow{2}{*}{ B vs C } & UL & 1.00 & 0.86 & 1.00 & 0.95 & 0.95 \\
\cline { 2 - 7 } & LL & 0.48 & 0.71 & 0.285 & 0.52 & 0.52 \\
\hline
\end{tabular}

In our series 16 patients presented before age of 3 months and 8 of them underwent valve ablation, in 4 vesicostomy was done and 4 was treated by high diversion. Similarly 56 patients who presented in 4-12 months of age 48 of them underwent valve ablation and 8 required vesicostomy. The 24 patients presented between 1-5 year of age 20 of them were treated with valve ablation and 4 required vesicostomy. 24 patients who presented after 5 years of age 16 were treated with valve ablation, 4 needed vesicostomy and 4 was treated by vesicostomy (Table 5 ).

Table 5: The mean age of presentation, valve ablation and the last follow up.

\begin{tabular}{|c|c|c|c|c|}
\hline \hline Group & Age Group & $\begin{array}{c}\text { Mean Age of Presentation } \\
\text { (Months) }\end{array}$ & $\begin{array}{c}\text { Mean Age of Valve Ablation } \\
\text { (Months) }\end{array}$ & $\begin{array}{c}\text { Mean Age of Last Follow Up } \\
\text { (Years) }\end{array}$ \\
\hline I & $0-3 \mathrm{~m}$ & 1.5 & 1.5 & 7 \\
\hline II & $4 \mathrm{~m}-1 \mathrm{yr}$ & 6.3 & 7.1 & 6.6 \\
\hline III & $1-5 \mathrm{yr}$ & 30 & 32 & 9.5 \\
\hline IV & $>5 \mathrm{yr}$ & 102 & 105 & 18 \\
\hline Mean & 34.95 & 36.4 & 10.3 & \\
\cline { 2 - 5 } Median & 1.5 & 18.15 & 8.2 & \\
\hline
\end{tabular}

92 patients who underwent primary valve ablation (treatment group - A) 64 of them require no further operative procedure. 8 patients underwent valve ablation with vesicostomy during follow-up. In 4 of these patients vesicostomy was closed and high diversion was done. The remaining 20 patients underwent valve ablation with high diversion. The 20 patients primarily treated with vesicostomy (treatment group - B) 12 of them undergone vesicostomy closure and 8 patients proceeded for high diversion. Those 8 patients primarily treated with high diversion (treatment group - C), 4 of them had bilateral ureterostomy and 4 had unilateral ureterostomy (Table 6).

Table 6: The number of cases: treated by primary mode of treatment in each age group.

\begin{tabular}{|c|c|c|c|c|c|}
\hline \multicolumn{2}{|c|}{ Age Group } & No. of Cases & Valve Ablation & Vesicostomy & High Diversion \\
\hline I & $0-3$ months & 16 & 8 & 4 & 4 \\
\hline II & $4-12$ months & 56 & 48 & 4 & 0 \\
\hline III & $13-60$ months & 24 & 20 & 4 & 0 \\
\hline IV & $>60$ months & 24 & 16 & 20 & 8 \\
\hline \multicolumn{2}{|c|}{ Total } & 120 & 92 & & 8 \\
\hline
\end{tabular}

In group I statistical correlation exist between patients treated with valve ablation, valve ablation + vesicostomy, $(\mathrm{p}<005)$ and valve ablation + high diversion, but no significant correlation exist between patients treated with valve ablation + vesicostomy and valve ablation + high diversion. In group II no significant correlation was observed between each treatment group and in group III statistical correlation could not be done. The most common subsequent procedure was ureteral reimplantation, followed by nephrectouretrectomy. The diversion group had significantly more reimplants. 92 (76\%) patients who underwent valve ablation among these 64 (69\%) of them has no subsequent open operative procedure in follow-up, 20 (21.7\%) 
patients underwent 1-2 open operative procedure and 8 (8.7\%) patients underwent more than 3 open operative procedures. The 20 patients (16.6\%) who underwent vesicostomy $12(60 \%)$ of them had 1-2 open procedure and $8(40 \%)$ had more than 3 open procedures. The 8 patients treated with high diversion $4(50 \%)$ required $1-2$ open operative procedure and $4(50 \%)$ required more than 3 open operative procedure. In valve ablation group 76 patients had vesiocureteric reflux among these VUR was resolved in 52 patients. In vesicostomy group 20 patients had VUR of which in 8 patients VUR subsided after primary treatment. In high diversion group 8 patients had VUR of which 4 resolved by its own and in 4 VUR persisted (Table $7 \& 8$ ).

Table 7: Number of patients those underwent operative procedure.

\begin{tabular}{|c|c|c|c|c|}
\hline Group & No. of Cases & Operative Procedure & No. of Cases & \\
\hline A. Valve Ablation & 92 & $\begin{array}{l}\text { Primary valve ablation } \\
\text { Valve ablation + vesicostomy } \\
\text { valve ablation + vesicostomy closure } \\
\text { valve ablation + vesicostomy closure + } \\
\text { high diversion } \\
\text { valve ablation + high diversion }\end{array}$ & $\begin{array}{l}64 \\
8 \\
4 \\
4 \\
\\
20\end{array}$ & $\begin{array}{c}16 \text { vs } 2, \mathrm{Z}=4.23 \\
\mathrm{p}<0.001 \\
2 \text { vs } 5, \mathrm{Z}=1.2 \\
\mathrm{p}=\text { no }(\mathrm{NS}) \\
16 \text { vs } 5, \mathrm{Z} 3.2 \\
\mathrm{p}<0.01\end{array}$ \\
\hline B. Vesicostomy & 20 & $\begin{array}{c}\text { Vesicostomy closure } \\
\text { Vesicostomy closure + high diversion }\end{array}$ & $\begin{array}{c}12 \\
8\end{array}$ & $\begin{array}{c}\mathrm{Z}=0.63 \\
\mathrm{p}=\mathrm{ns}\end{array}$ \\
\hline C. High Diversion & 8 & $\begin{array}{l}\text { Bilateral Ureterostomy } \\
\text { Unilateral Ureterostomy }\end{array}$ & $\begin{array}{l}4 \\
4\end{array}$ & - \\
\hline
\end{tabular}

Table 8: Incidence of VUR: at time of diagnosis of PUV in each treatment group.

\begin{tabular}{|c|c|c|c|}
\hline & \multicolumn{3}{|c|}{ No of patients with VUR } \\
\hline & $\begin{array}{c}\text { Initial } \\
\text { treatment }\end{array}$ & After & Faith \\
\hline $\begin{array}{c}\text { Group A } \\
\text { Valve Ablation }\end{array}$ & $\begin{array}{c}G-V-8 \\
G-I V-32 \\
G-I I I-8 \\
G-I I-28\end{array}$ & $76 / 92$ & $\begin{array}{c}52 \text { resolved } \\
8 \text { reimplantation } \\
8 \text { spontaneous resolution } \\
8 \text { persistent grade I VUR }\end{array}$ \\
\hline $\begin{array}{c}\text { Group B } \\
\text { Vesicostomy }\end{array}$ & $\begin{array}{l}G-V-8 \\
G-I V-8 \\
G-I I I-4\end{array}$ & $20 / 20$ & $\begin{array}{c}8 \text { resolve } \\
4 \text { reimplantation } \\
4 \text { persistent grade II } \\
4 \text { persistent grade I }\end{array}$ \\
\hline $\begin{array}{c}\text { Group } C \\
\text { High diversion }\end{array}$ & $G-V-8$ & $8 / 8$ & $\begin{array}{c}4 \text { resolve } \\
4 \text { persistent grade } V\end{array}$ \\
\hline
\end{tabular}

Out of 16 patients presented before 3 months of age 8 had normal growth and development, 4 had grade I PEM, and 4 had grade II PEM. In group II 32 was normal, 8 had grade I PEM, and 8 had grade II PEM, 4 each in grade III \& IV. In group III, 12 patients had normal growth and development and 4 each in I, III, IV PEM grade. In group IV 16 patients had normal growth and development and 4 each in II \& IV PEM grade (Table 9).

Among total of 120 patients, 92 (76\%) patients underwent primarily valve ablation $8(8.7 \%)$ of them develop CRF and $4(4.4 \%)$ patients progressed to ESRD and remaining 20 (66\%) were normal. Among 20 patients (16.6\%) treated with vesicostomy $4(3.3 \%)$ had CRF, 4 (3.3\%) progressed to ESRD and $12(10 \%)$ had normal life. In the patients treated with high diversion 4 (3.3\%) developed CRF and 4 (3.3\%) progressed to ESRD.

\section{Table 9:}

\begin{tabular}{|c|c|c|c|c|c|c|}
\hline \hline & \multicolumn{2}{|c|}{ Normal for Age } & $\begin{array}{c}\text { Grade - I } \\
\text { PEM }\end{array}$ & $\begin{array}{c}\text { Grade - II } \\
\text { PEM }\end{array}$ & $\begin{array}{c}\text { Grade - III } \\
\text { PEM }\end{array}$ & $\begin{array}{c}\text { Grade - IV } \\
\text { PEM }\end{array}$ \\
\hline Groups & No. & $>\mathbf{8 0} \%$ & $\mathbf{7 1 - 8 0 \%}$ & $\mathbf{6 1 - 7 0 \%}$ & $\mathbf{5 1 - 6 0 \%}$ & $<\mathbf{5 0 \%}$ \\
\hline $0-3$ mths & 16 & 8 & 4 & 0 & 4 & 0 \\
\hline $4-12$ mths & 56 & 32 & 8 & 8 & 4 & 4 \\
\hline $13-60$ mths & 24 & 12 & 4 & 0 & 4 & 4 \\
\hline$>60$ mths & 24 & 16 & 0 & 4 & 0 & 4 \\
\hline & 120 & 68 & 16 & 12 & 12 & 12 \\
\hline
\end{tabular}

Among 92 patients who were primarily treated by valve ablation (group-A) 24 of them required high urinary diversion during follow up and 8 of these patients progressed to ESARD. In patients who were primarily treated with vesicostomy (group-B) among them 8 required high diversions and 4 of them developed CRF and 4 progressed to ESRD. In high diversion group (group-C) 4 developed CRF and 4 progressed to ESRD (Table 10). 
Table 10: Table showing: the sequel of PUV in each treatment group during follow up.

\begin{tabular}{|c|c|c|c|c|c|}
\hline Treatment Group & No. & CRF & ESRD & Normal Life & \\
\hline Group A & $92(76.6 \%)$ & 8 & 4 & $80(86.9 \%)$ & $\begin{array}{c}2 \text { vs } 20, Z=5.3 \\
p<0.001 \\
2 \text { vs } 1, Z=0.6 \\
p(N S) \\
1 \text { vs } 20, Z=5.6 \\
\text { p }<0.001\end{array}$ \\
\hline Group B & $20(16.6 \%)$ & $4(20 \%)$ & $4(20 \%)$ & $12(60 \%)$ & $\begin{array}{c}3 \text { vs } 1, Z=1.29 \\
p(N S)\end{array}$ \\
\hline Group C & $8(6.2 \%)$ & $4(20 \%)$ & $4(20 \%)$ & 0 & $\mathrm{Z}=1.16 \mathrm{p}(\mathrm{NS})$ \\
\hline
\end{tabular}

Incontinence of urine was noticed in 28 (23\%) (66.6\%) patients. Sub renal clearance was found in 72 (60\%). patients Cortical scarring was observed in $44(36.6 \%)$ of patients (Table

DMSA/DTPA renal scans showed hydronephrosis in 64 $11 \& 12)$. (53\%). Renal parenchyma function was also impaired in 80 Table 11: Long term follow up sequel of bladder dysfunction in PUV patients.

\begin{tabular}{|c|c|c|c|c|c|c|}
\hline \hline Group & $\begin{array}{c}\text { Age of } \\
\text { Presentation }\end{array}$ & $\begin{array}{c}\text { Mean age of } \\
\text { Presentation }\end{array}$ & $\begin{array}{c}\text { Mean Age at last } \\
\text { Follow Up }\end{array}$ & \multicolumn{2}{|c|}{ Incontinent } \\
\hline I & $0-3 \mathrm{~m}$ & 1.5 months & 7 year & 4 & $3.3 \%$ & 82.5 \\
\hline II & $4-12 \mathrm{~m}$ & 6.3 months & $6.6 \mathrm{yr}$ & 8 & $6.6 \%$ & 72.9 \\
\hline III & $13-60 \mathrm{~m}$ & 30 months & $9.5 \mathrm{yr}$ & 4 & $3.3 \%$ & 84 \\
\hline IV & $>60 \mathrm{~m}$ & 102 months & $18 \mathrm{yr}$ & 12 & $10 \%$ & 114 \\
\hline & & 34.95 months & $10.3 \mathrm{yr}$ & 28 & $23.3 \%$ & 88.35 \\
\hline
\end{tabular}

Table 12: Number of cases having deranged ERPF, hydronephrosis, abnormal size, deranged subrenal clearance and parenchymal function of kidney on DTPA \& DMSA Scan.

\begin{tabular}{|c|c|c|c|c|c|c|c|c|c|c|c|c|}
\hline & \multicolumn{2}{|c|}{ HD } & \multicolumn{2}{|c|}{ Size } & \multicolumn{2}{|c|}{ PF } & \multicolumn{2}{|c|}{ SRL } & \multicolumn{2}{|c|}{ ERPF (<20\%) } & \multicolumn{2}{|c|}{ Scarring } \\
\hline & UL & BL & UL & BL & UL & BL & UL & BL & UL & BL & UL & BL \\
\hline No of cases & 32 & 24 & 16 & 32 & 64 & 16 & 56 & 20 & 80 & 8 & 20 & 24 \\
\hline
\end{tabular}

\section{Discussion}

PUV are the most common cause of intravesical obstruction in males. Historically, the treatment was bladder decompression with a bladder catheter and then sequential renal function assessment. Patients who did not respond to the initial bladder drainage with a decrease in creatinine of $10 \%$ daily to a nadir of less than $0.8 \mathrm{mg} / \mathrm{dL}$ by day 5 were treated with high urinary diversion $[5,6]$ (Table 3). The role of urinary diversion in patients with PUV has been questioned [7-10] and it was thought that the renal function in these patients was not influenced by the initial therapy. Proponents of high urinary diversion believe that by draining the pelvicaliceal system, the renal function improves temporarily, thus delaying the need for transplantation. Those against upper tract diversion state that these patients are born with renal dysplasia and are prone to progressive renal failure, irrespective of the treatment at presentation. The renal dysplasia is secondary to abnormal caudal budding of the ureter from the mesonephric duct with subsequent abnormal induction of the mesenchyme.

In our study $60 \%$ of patients were less than 1 year old [11] which is similar to the other studies. In our series obstructive symptom in the form of poor stream and dibbling were present in $76.6 \%$ of cases, severe septicemia with respiratory distress in $16.7 \%$ and $6.3 \%$ presented with failure to thrive [12]. On physical finding bladder was hypertrophied and palpable in $43.3 \%$ patients and kidney was palpable in $33.3 \%$ of cases [13]. In our series $10 \%$ patients presented with urinary ascitis. Blood urea and creatinine as reported by others were high in these children at the time of presentation. Average blood urea and creatinine was highest in group I. The direct correlation of blood urea level at time of presentation was not noticed in our series as had been reported in others [12]. But on the whole higher initial blood urea and creatinine level indicated a poorer prognosis [14]. At presentation $>95 \%$ patients had raised blood urea and creatinine level and after 1 month follow up it was higher in $57 \%$ of cases and after 1 year $33 \%$ patients had mean serum creatinine level more than $2.9 \mathrm{mg} / \mathrm{dl} .10 \%$ of cases had serum level $>4.3 \mathrm{mg} / \mathrm{dl}$ at mean of 7.5 year of follow up. In our series $23.3 \%$ patients had raised serum creatinine level $(3.9 \mathrm{mg} /$ dl) between 1-5 years of follow up, after this period only $10 \%$ patients had elevated mean serum creatinine $(4.4 \mathrm{mg} / \mathrm{dl})$ at 7.5 mean year of follow up and they rapidly progressed to ESRD with rapid increase in mean serum level.

Voiding cystourethrogram (VCU) was done to reach definitive diagnosis and to document the VUR. In our series 104 (86.7\%) presented with reflux and during follow up 84 patients showed resolution after surgical correction. 
Prevalence of VUR was quite high in our series $(86.6 \%)$ compared to other studies [15] but is similar to other studies [16]. Unilateral reflux was seen in $53.3 \%$ of cases and bilateral reflux was seen in $33.6 \%$ cases. Highest incidence of reflux was seen in group-1 (63.3\%).Up to $50 \%$ of VUR resolves spontaneously following treatment of the valves and relief of infravesical obstruction. In our series spontaneous resolution was noted in $43.3 \%$ of cases which is similar to other series [16]. Most persisting VUR is treated conservatively and is not a significant prognostic factor for renal function on follow-up [17]. Presence of bilateral VUR with posterior urethral valve implies a worse prognosis [18].

Primarily the treatment of PUV is valve ablation. Urinary diversion is usually performed in the severe cases. As an initial procedure vesicostomy is superior to ureterostomy because it provides better bladder compliance. Supravesical diversion can be reserved for those patients who failed to vesicostomy. The number of open surgical procedure is greatly increased in diversion like; ureteral reimplantation, nephrectomy, stomal revision. We have noted that $50 \%$ of diversion group underwent 3 or more procedure excluding the valve ablation which is similar to other reported series [19]. The outcomes for primary valve ablation compared with vesicostomy and delayed valve ablation are similar. In our series patients primarily treated with vesicostomy showed satisfactory growth pattern as stated by other studies.

On long term follow up normal growth status was achieved in $69 \%$ cases of treatment group-A and $20 \%$ in treatment group-B and none $\mathrm{n}$ group-C. which is similar to other studies. In our series $31 \%$ patients in nondiversion group and $50 \%$ of diversion group progress to ESRD which is similar to other series. The mean age of progression to ESRD from the time of diagnosis was 10.7 years of follow up in our series which similar to other studies $[20,21]$. In long term prognosis of bilateral reflux is worse however unilateral massive reflux is regarded as pop-off mechanism to protect opposite kidney and hence is better prognostic sign. VUR was present in $86.6 \%$ cases $(53.3 \%$ unilateral and $33.3 \%$ bilateral) reimplantation was required in $10 \%$ of cases. Aggressive treatment of VUR with early surgical intervention is rarely justified as it resolves spontaneously in some cases. Despite of the type of primary surgical treatment (valve ablation, vesicostomy or high diversion) renal failure still develops in $23 \%$ of cases. Bladder dysfunction was present in $(23.3 \%)$ of cases in our study, which may occur after valve ablation as (13-18\%) in other studies [22].

In our study overall mortality was 10\% (ESRD). Highest percentage being in groups of patients treated primarily with high diversion (treatment group-C). In our series $13.3 \%$ of cases developed CRF on long term follow and $76.7 \%$ of cases were enjoying normal life without any sequel.

\section{Conclusion}

Posterior urethral valve is a dynamic disease that can have lifelong effects on bladder. These patients need long term follow up care to monitor and treat the effects of altered bladder compliance.

\section{References}

1. Thomas DFM, Hutton KAR (1994) Posterior urethral valves. Eur Urol Update Ser 3: 34-39.

2. Hendren WH (1971) Posterior urethral valves in boys: a broad clinical spectrum. J Urol 106(2): 298-302.

3. Bomalaski MD, Anema JG, Coplen DE, Koo HP, Rozanski T (1999) Delayed presentation of posterior urethral valves a not so benign condition. J Urol 162(6): 2130-2132.

4. Jaswon MS, Dibble L, Puri S, Davis S, Young J, et al. (1999) Prospective study of outcome in antenatally diagnosed renal pelvis dilatation. Arch Dis Child 80(2): F135-F138.

5. Krueger P, Hardy BE, Churchill BM (1980) Growth in boys and posterior urethral valves: primary valve resection vs upper tract diversion. Urol Clin North Am 7(2): 265-272.

6. Churchill M, McLorie GA, Khoury AE, Merguerian PA, Houle AM (1990) Emergency treatment and long-term follow-up of posterior urethral valves. Urol Clin North Am 17(2): 343-360.

7. Reinberg Y, de Castano I, Gonzalez R (1992) Influence of initial therapy on progression of renal failure and body growth in children with posterior urethral valves. J Urol 148(2 Pt 2): 532-533.

8. Tietjen DN, Gloor JM, Husmann DA (1997) Proximal urinary diversion in the management of posterior urethral valves: is it necessary? J Urol 158(3 Pt 2): 1008-1010.

9. Smith GH, Canning DA, Schulman SL, Snyder HM, Duckett JW, et al. (1996) The long-term outcome of posterior urethral valves treated with primary valve ablation and observation. J Urol 155(5): 17301734.

10. Close E, Carr MC, Burns MW, Mitchell ME (1997) Lower urinary tract changes after early valve ablation in neonates and infants: is early diversion warranted? J Urol 157(3): 984-988.

11. Ellis DG, Fonkalsrud EW, Smith JP (1996) Congenital posterior valves. J Urol 95: 549.

12. Garg Sk, Lawrie JH (1983) The perineal urethrostomy approach to posterior rethral valves. J Urol 130(6): 1146.

13. Atwell JD (1974) Posterior urethral valves in British Isles - A multicenter B.A.P.S. Review. J Ped Surg 18(1): 280.

14. Denes ED, Barthold JS, Gonzalez R (1997) Early prognostic value of serum creatinine levels in children with posterior urethral valves. J Urol 157(4): 1441-1443.

15. Parkhouse HF, Ban-ett TM, Dhillion MJ, Duffy PG, Fay J, et al. (1988) Longterm outcome of boys with posterior urethral valve $\mathrm{Br} \mathrm{J}$ Urol 62(1): 59-62.

16. Puri P, Kumar R (1996) Endoscopic correction of vesiocureteric reflux secondary to posterior urethral valves. J Urol 156: 680-682.

17. Hassan M, Pope JC, Brock JW, Adams MC (2003) Vesicoureteral reflux in patients with posterior urethral valves. J Urol 170: 1677-1680.

18. Glassberg KL, Schneider M, Haller Jo, Moel D, Waterhouse K (1982) Observations on persistently dilated ureter after posterior urethral valves ablation. Urology 20(1): 20-28.

19. Smith GH, Canning DA, Schulman SL, Snyder HM, Duckett JW (1996) The long-term outcome of posterior urethral valves treated with primary valve ablation and observation. J Urol 155(5): 1730-1734.

20. Drozdz D, Drozdz M, Gretz N, Mohring K, Mehls O, et al. (1998) Progression to end-stage renal disease in children with posterior urethral valves. Pediatr Nephrol 12(8): 630-636. 
21. Warshaw BL, Ettenger RB, Pennisi AJ, Fine RN (1982) Progression to end-stage renal disease in children with obstructive uropathy. J Pediatr 100(2): 183-187.

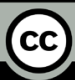

This work is licensed under Creative Commons Attribution 4.0 License

DOI: 10.19080/JOJUN.2018.05.555654

\section{Your next submission with Juniper Publishers} will reach you the below assets

- Quality Editorial service

- Swift Peer Review

- Reprints availability

- E-prints Service

- Manuscript Podcast for convenient understanding

- Global attainment for your research

- Manuscript accessibility in different formats

( Pdf, E-pub, Full Text, Audio)

- Unceasing customer service

Track the below URL for one-step submission https://juniperpublishers.com/online-submission.php 